\title{
„Díky, Ameriko!‘‘: dramaturgická analýza Slavností svobody v „nejameričtějším“ městě Evropy ${ }^{1}$
}

\author{
“Thanks, America!": A Dramaturgical Analysis of the Liberation Festival \\ in the "Most American" city in Europe
}

PETR KRČÁL, VLADIMÍr NAXERA ${ }^{2}$

\begin{abstract}
The following article aims to provide an interpretation of the annual public occasion called the "Liberation Festival" in Pilsen. The Liberation Festival serves as a celebration of the liberation of Pilsen by the U.S. army. Our paper presents a dramaturgical analysis of this occasion. More specifically, our effort is focused on two main interpretative threads. With respect to the first one (called "the production of discourse") we analyse the processes of the (re)production of political discourse related to this public occasion. We also identify the main discourse that is typically produced or reinforced during the Liberation Festival. The second interpretative thread is called "the organizational line of the Liberation Festival". Here, we try to provide examples and identify characteristics of the strategies and practices that can be employed by state apparatuses to present themselves as guarantors of the security of festival goers. Our findings confirm that public ceremonies (like the Liberation Festival) can fulfil the role of a medium that serves to spread actual political discourse, the veneration of actual societal normative order, and a positive portrait of state apparatuses. Our article can thus be viewed as a contribution to the debate on the reproduction of political discourse through public spectacles.
\end{abstract}

Keywords: Dramaturgical Analysis; Liberation Festival; Pilsen; Politicians; Reproduction of Discourse; Security; Symbolic Communication

1 Text vznikl jako výstup grantu „SGS-2015-015 - Stát a politická moc - vybraná témata aplikované politické teorie“", který byl poskytnut Západočeskou univerzitou v Plzni; zpracování textu bylo podpořeno také z Institucionální podpory na dlouhodobý koncepční rozvoj výzkumné organizace 2015 Katedry politologie a mezinárodních vztahů FF ZČU.

2 PhDr. Petr Krčál, Ph.D. a PhDr. Vladimír Naxera, Ph.D., odborní asistenti, Katedra politologie a mezinárodních vztahů, Fakulta filozofická ZČU v Plzni, Česká republika, Univerzitní 8, 30614 Plzeň / Department of Politics and International Relations, Faculty o Philosophy and Arts, University of West Bohemia, Czech Republic. Contact:; petrkrcal@gmail.com (Petr Krčál); vnaxera@kap.zcu.cz (Vladimír Naxera). 


\section{1. Úvodem}

„[V] rannich hodinách 6. června 1944 zabájila spojenecká vojska vylodèním v Normandii útok proti jednotkám Wermachtu. Den D, den, kedy zapoćala bitva o Normandii, se stal jednou

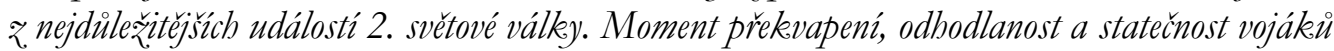
slavily úspèch, začalo osvobozováni evropského kontinentu, keteré trvalo až do kvètna 1945.

Nèkteré jednotky, které na plážich Normandie bojovaly, došly prì své cestě za vitězstvím å̆ do Plinne.. 3

„Mèsto Plzeñ se dikey jedné z nejvýznamnèjš̌ch historickéch událostí minulého století, konci II. svètové války, která zásadné ovlivnila osudy obyvatel Evropy, ocitlo v ojedinèlé pozici. Jako jedno z. mèst osvobozených v kvètnu 1945 je poslednim skutečným i symbolickým mistem, kde skončila cesta spojeneckých vojsk evropským kontinentem. Mèstem, které symbolicky spojuje Francii, Lucembursko, Belgii a Ceskou republiku.“ 4

Výše uvedené citáty jsou převzaty z oficiálních internetových stránek plzeňských Slavností svobody a volně ilustrují to, na co budeme $v$ našem textu odkazovat. Cílem naší snahy je předložit čtenáři interpretaci 70. výročí Slavností svobody, které představují každoročně se opakující veřejnou událost, jejímž záměrem je ceremoniální oslava osvobození Plzně spojeneckými vojsky, respektive jednotkami americkými a belgickými. Slavnosti svobody jsou de facto zastř̌ešujícím termínem pro množství parciálních událostí odehrávajících se na různých místech $\mathrm{v}$ Plzni $\mathrm{v}$ různých dnech. Tematickým pojítkem těchto událostí je právě ceremoniální oslava osvobození Plzně v závěru 2. světové války. $\mathrm{Na}$ těchto událostech je na jedné straně přítomno značné množství přihližejících, ${ }^{5}$ na straně druhé představují partikulární akce v rámci Slavností svobody př́ležitost jak pro lokální a regionální politické představitele, tak i pro politiky celostátního významu k tomu, aby mohli (re)produkovat diskurzy, které jsou z jejich pohledu signifikantní. Tyto diskurzy souvisely především s oslavou demokratických hodnot a také s vytvářením metafory Ruska jako hrozby a Spojených států jako obránců svobody a bezpečnosti $\mathrm{v}$ současném (i minulém) světě. $Z$ tohoto je možné odvodit první interpretační linii, které se budeme v textu držet - v textu se pokusíme rozkrýt procesy diskurzivní (re)produkce témat, která rezonovala ze strany participujících (lokálních a celostátních) politických elit.

Druhou linii je možné odvodit ze skutečnosti, že Slavnosti svobody patří mezi hojně navštěvovanou veřejnou událost. S ohledem na to je logické,

\footnotetext{
${ }^{3}$ Převzato z http://www.slavnostisvobody.cz/.

4 Převzato z http://www.slavnostisvobody.cz/slavnosti-svobody/slavnosti-svobody-2012.aspx.

5 Podle odhadů organizátorů se letos všech těchto akcí účastnilo zhruba 180 tisíc jedinců - oproti předchozím ročníkům šlo o výrazný nárůst, který je přikládán jednak tomu, že se jednalo o kulaté výročí, a zároveň tomu, že v roce 2015 byla Plzeň evropským hlavním městem kultury, což zvýšilo např́klad počty turistů.
} 
že ve chvíli konání představují důležitý bod zájmu složek státního aparátu, které se na této události snaží zajistit a udržovat bezpečnost. Z tohoto pohledu se pokusíme $\mathrm{v}$ našem textu charakterizovat to, jakými konkrétními způsoby slouží veřejné události typu plzeňských Slavností svobody jako akce, která napomáhá ke konstrukci percepce státních aparátů jakožto garantů bezpečnosti „spořádaných občanư“.

Poslední linii, ve které se budeme při analýze Slavností svobody pohybovat, je možné uvést tvrzením, že srozumitelně a logicky reprodukovaná minulost může vést $\mathrm{k}$ posilování důvěry společnosti $\mathrm{v}$ aktuální hodnotový systém tím, že napomáhá $\mathrm{k}$ prezentaci historické návaznosti hodnot, ke kterým se daný politický systém hlásí (srov. Keller 2003: 76). Z tohoto pohledu tak je možné plzeňské Slavnosti svobody vnímat jako veřejnou událost, jejíž symbolický význam spočíá $\mathrm{v}$ adorování demokracie prostřednictvím referenčního bodu, kterým je $\mathrm{v}$ tomto př́padě 2 . světová válka.

Tuto část úvodu můžeme uzavrít tím, že Slavnosti svobody se pokusíme nahlížet ve třech liniích. Linie týkající se toho, jak konkrétně dochází ze strany př́tomných politických představitelů $\mathrm{k}$ (re)produkci jimi požadovaného diskurzu (a také reprodukci vlastního politického kapitálu), a toho, jak slouží Slavnosti svobody k symbolickému vyzdvihování demokratických hodnot, můžeme označit jako linii diskurzivní produkce. Linii toho, jakými způsoby napomáhají Slavnosti svobody k utváření percepce státních aparátů jakožto garantů bezpečnosti spořádaných občanů, můžeme nahlížet jako linii organizační.

$\mathrm{V}$ rámci partikulárních akcí v rámci Slavností svobody (podrobná interpretace viz níže $v$ textu) ze strany participujících politických představitelů několikrát zaznělo, že Plzeň je určitou výjimkou v českém kontextu, protože velmi silně oslavuje úlohu americké armády. ${ }^{6}$ Důležitost americké armády je patrná i v tom, že v centru Plzně (na Americké ulici) se nachází pomník s názvem „Díky, Ameriko!“”, v tom, že v rámci Slavností svobody uvařil plzeňský pivovar speciální

6 To je, vzhledem k tomu, že Plzeň byla osvobozena americkou armádou, poměrně logickým krokem. Kromě níže zmíněných př́íladů můžeme pro ilustraci uvést skutečnost, že se v Plzni nachází celá řada pomníků, pamětních desek atd. spojených s americkým osvobozením (dvě z nich např́klad prímo v budově historické radnice na náměstí Republiky). Tyto pomníky se (společně s objekty starších plzeňských dějin a nově do velké míry také industriálními památkami) staly privilegovanými prostory městské paměti v Plzni (Burzová 2014; Burzová et al. 2013). Zajímavé je také to, že plzeňský hokejový tým má od roku 2009 v klubovém znaku profil indiána, který odpovídá znaku 2. pěší divize armády USA, jež osvobodila Plzeň. Tato divize, která nyní působí v Koreji, užívá daný znak doposud.

7 Zde nalézáme další symbolické vyjádření pocty americkému osvobození - jedna z nejrušnějších tepen v centru Plzně nesla po vzniku Československa název Jungmannova, v době protektorátu Bahnhofstraße, po osvobození roku 1945 byla přejmenována na Americkou, po vzniku komunistického režimu na Moskevskou a po jeho pádu se symbolicky navrátila k poválečnému názvu. Tento projev specifické geografie vzpomínání a zapomínání, který často souvisí právě s přejmenováváním ulic, je potvrzením důležitosti paměti v postsocialistickém sociálním a politickém životě (Burzová 2014), Plzeň nevyjímaje. 
edici piva s americkým chmelem, nebo $\mathrm{v}$ tom, že v průběhu oslav byl odhalen pomník generálu Pattonovi, který velel vojsku, jež Plzeň osvobodilo - k tomuto odhalení se dostaneme níže, nebot' šlo o jednu z námi analyzovaných akcí. Dobrým příkladem adorování americké armády je také skutečnost, že při odhalování Pattonova pomníku zaznělo ze strany účinkujících, že Plzeň je díky tomu, jakým způsobem rámuje události spojené s jejím osvobozením, „nejameričtější město v Evropě“ (a tato fráze se kontinuálně opakovala i na dalších veřejných událostech napojených na Slavnosti svobody, interpretace viz níže). Hlavním cílem předkládaného textu je snaha o poskytnutí interpretace každoročně se opakujících oslav osvobození v Plzni se zaměřením na Slavnosti svobody v roce 2015 pohledem dramaturgické analýzy. Tento ročník oslav byl specifický tím, že se jednalo o sedmdesáté výročí osvobození Plzně, což se projevilo např́klad i silným zastoupením ústavních a dalších politických činitelů na závěrečné ceremonii (viz níže). V obecném kontextu může tento text přispět zejména $\mathrm{k}$ porozumění tomu, jakým zpơsobem mohou veřejné události sloužit jako nástroj $\mathrm{k}$ reprodukci politického diskurzu.

Data, která budeme dále $\mathrm{v}$ textu interpretovat, jsme zkonstruovali na základě polozúčastněného pozorování vybraných událostí v rámci Slavností svobody ve dnech 2. až 6. května $2015 .^{8}$ Konkrétně jsme se na Slavnostech svobody věnovali polozúčastněnému pozorování těchto akcí: „Zahájení Slavností svobody Plzeň za účasti válečných veteránư‘**, „Odhalení pomníku generála G. S. Pattona“** (oboje 1. května); „Program klubů vojenské historie“, „Prezentace Městské policie Plzeň“ a kulturních akcí na náměstí Republiky (vše 2. května); „Convoy of Liberty“ (3. května); „Plzeň 1945“ (4. května); „Pietní akt u památníku Obětem 2. světové války a padlým československým a spojeneckým letcům“* (5. května); „Vzpomínkový akt u památníku „Díky, Ameriko!““‘** (6. května). ${ }^{9}$ Hlavní výklad bude postaven na analýze čtyř výše zmíněných událostí označených hvězdičkou - právě na nich byla totiž silná politická účast. Poznatky $\mathrm{z}$ dalších událostí budou využity spíše $\mathrm{k}$ dokreslení kontextu a podpoření naší argumentace. Druhým zdrojem dat byly rozhovory se zainteresovanými aktéry. ${ }^{10}$ Jako vhodný nástroj pro interpretaci dat se nám jeví dramaturgická analýza, která umožňuje redukovat a nahlížet veřejné události jako specifická divadelní představení, jejichž prostřednictvím se snaží různí aktéři navodit a udržet jimi požadované definiční situace (srov. Goffman 1999). Vrátíme-li se ke dvěma hlavním složkám slavností, na které v textu zaměřujeme, můžeme konstatovat, že v linii diskurzivní produkce představují hlavní aktéry lokální a celostátní politické elity a ostatní jedinci, kteří se v roli „mluvčích“ prezentovali

\footnotetext{
$8 \mathrm{Na}$ tomto místě chceme poděkovat Bc. Lucii Čavojské a Bc. Tereze Špačkové, které nám pomáhaly s tvorbou dat z veřejných událostí.

${ }^{9}$ Kompletní program viz zde: http://www.slavnostisvobody.cz/slavnosti-svobody/program/.

$10 \mathrm{Ti}$ budou $\mathrm{v}$ tomto textu $\mathrm{z}$ důvodu zachování akademické etiky práce s respondenty plně anonymizováni.
} 
na jednotlivých událostech. V linii organizační jsme za hlavní aktéry považovali prŕslušníky státní a městské policie.

\section{Stručná charakteristika Goffmanova teoreticko- metodologického rámce}

V této části textu se zaměříme na stručnou charakteristiku dramaturgické analýzy. ${ }^{11}$ Teoreticko-metodologický rámec dramaturgické analýzy Ervinga Goffmana je ukotven v pozicích symbolického interakcionismu a sdílí s ním tři vzájemně propojené premisy. První z nich je ta, že jedinci přiřazují skutečnostem specifické významy, podle nichž jednají. Druhou je předpoklad, že specifické významy jsou odvozeny z interakčních procesů. Třetí premisa se týká toho, že obsah významů je upravován $\mathrm{v}$ interakčních procesech s ostatními jedinci (viz Blumer 1969). Vycházeje z těchto předpokladů, nahlíží Erving Goffman chování jedinců a jejich prezentace na veřejných událostech jako na pečlivě přpravená a naplánovaná divadelní představení. V rámci těchto divadelních představení se snaží aktéři o to, aby navodili a udrželi jimi požadované situační definice, a k podpoření své snahy volí vhodné (pokud možno symbolické) prostředí, datum a kulisy (srov. Goffman 1999).

Při využívání tohoto metodologického rámce je vhodné vycházet z trojî dichotomizace analyzované události. První z nich je rozdělení aktérů přítomných na veřejné události na přihlížející a účinkující. Každá z těchto skupin musí určitým způsobem regulovat své jednání a opírá se o odlišné imperativy. Skupina účinkujících usiluje o nastolení a udržení situační definice; aby tohoto cíle dosáhla, je nezbytné, aby její členové postupovali podle předem daných schémat a dodržovali dramaturgickou ukázněnost a vzájemnou loajalitu. Oproti tomu skupina prihlížejících by měla kontrolovat své reakce na prezentace účinkujících. S ohledem na skutečnost, že obě skupiny jednají podle odlišných regulativů, hovoři Goffman o tom, že si každá ze zúčastněných stran může utvořit a prosazovat svoji vlastní situační definici (viz Goffman 1966 a 1986). V našem př́padě se skupina účinkujících skládá z přítomných politických aktérů, kteří se $\mathrm{v}$ rámci svých prezentací snažili utvořit konzistentní definice situace a tím (re)produkovat jimi požadovaný politický diskurz. Účinkující můžeme vnímat jako členy týmu, který budeme v textu označovat jako „politický tým“. Dalšími účinkujícími jsou v naší perspektivě př́slušníci státní a městské policie, které v textu budeme zahrnovat pod termín „tým státních aparátư“. V př́padě týmových prezentací je klíčové to, že všichni členové týmu musí dodržovat předem daná schémata a dávat si pozor na to, aby nepodali takový výkon, který by měl negativní (prípadně destruktivní) dopad na předkládanou definici situace (viz Goffman 1999).

${ }^{11}$ Podrobněji např́klad Krčál a Naxera (2011). 
Druhou dichotomizací, kterou je nutné brát na analyzované události v potaz, je rozdělení sebeprezentací aktérů do dvou hlavních prostorových regionů, které jsou podle Goffmana (1999: 108) vnímány jako místa „do určitého stupně obraničené bariérami vnímáni". Tyto regiony jsou v souladu s dramaturgickou analýzou označovány jako jeviště (nebo také přední region) a jako zákulisí (nebo také zadní region). Jeviště označuje taková místa, ze kterých probíhá interakce účinkujících směrem $\mathrm{k}$ přihlížejícím. Snahou účinkujících na jevišti je navození zdání toho, že jejich představení naplňuje a zachovává určité normy. Na jevišti se tak odehrává představení mající za úkol předložit a upevnit požadovanou situační definici. K tomuto představení se pojí určité časové a prostorové limity a jeviště disponuje jedním ohniskem vizuální pozornosti (viz Goffman 1999). V rámci námi analyzovaných událostí lze konstatovat, že týmy, které jsou na nich př́tomné, odehrávají své situační definice jak na statických jevištích (nap̌r. odhalení pomníku

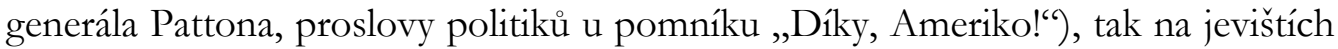
dynamických (např́klad průjezd historických vozidel centrem Plzně). Je patrné, že přední region představuje prostor, který je ze strany účinkujících využíván $\mathrm{k}$ tomu, aby (re)produkovali jimi požadovaný diskurz. Oproti tomu zákulisí slouží $\mathrm{k}$ tomu, aby se zde aktéri přpravovali na odehrávání svých rolí v předním regionu. Zákulisí plní v rámci analyzované akce podpůrnou roli ve vztahu k jevišti a jeho účelem je poskytnout zázemí „,hereckým týmům“ pro př́pravu rolí, které budou sehrávat na jevišti. $Z$ tohoto důvodu by měl být tento prostor vyčleněn ze zorného pole publika (Goffman 1999: 114). Zákulisí na analyzovaných akcích můžeme vnímat jako prostor, kde se účastníci připravují na předkládání situačních definic. Pro účastníky veřejné události představuje zadní region často prostor, kde se scházejí před samotným začátkem veřejné akce; zadní region velmi často zanikne ve chvíli, kdy analyzovaná událost začne a celá se následně přetransformuje $\mathrm{v}$ přední region.

Třetí dichotomizace analyzované akce vychází z dělení samotných událostí, které v rámci události probíhají. Konkrétně je lze dělit na události hlavní a podružné. Cílem hlavních událostí je předkládání situačních definic. Oproti tomu podružné události slouží jako podpưrné akty k napomáhání předkládání těchto definic a jejich organizační logika podléhá událostem hlavním (viz Branaman a Lemert eds. 1997). V rámci Slavností svobody můžeme hovořit o tom, že hlavní události byly tvořeny napríklad proslovy politiků u pomníku „Díky, Ameriko!“, odhalení pomníku generála Pattona, prŕpadně proslovy politiků $\mathrm{k}$ poctě válečných veteránů na plzeňském náměstí Míru. Jako podružné události můžeme vnímat expozici dobového kempu armády Spojených států, př́padně další doprovodný kulturně-zábavný program ve formě reprodukované a živé muziky, doplňkových stánků s občerstvením a suvenýry a podobně.

V souvislosti s představeným teoreticko-metodologickým aparátem dramaturgické analýzy považujeme za vhodné poukázat i na některé limity tohoto prristupu, které lze rozdělit na limity „technické“ a „epistemologické“. Technický 
limit může spočívat ve finanční a organizační náročnosti tohoto přístupu, jelikož je nezbytně nutné, aby na pozorované akci bylo prrítomné větší množství pozorovatelů (zejména na tak rozsáhlých akcích, jako jsou Slavnosti svobody). Takovýmto pozorováním poté bývá vyprodukována značně rozsáhlá sada dat $\mathrm{s}$ různou relevancí, které je $\mathrm{v}$ rámci vlastní analýzy a interpretace třeba podrobit selekci a zpracování, což zároveň vytvárí první epistemologický problém. R̉ada dat totiž může nabývat zdání značné relevance a prŕnosu v kontextu sledované akce, ale v rámci širšího sociálního a politického kontextu se ukazuje jako irelevantní, př́padně jako triviální. Jak uvádíme níže $\mathrm{v}$ textu, $\mathrm{v}$ průběhu námi sledovaných událostí došlo ze strany herců k produkci několika různých diskurzů, které byly publikem přijímány. Z pohledu dramaturgické analýzy ovšem je velmi těžko rozlišitelné, zda byl daný diskurz $\mathrm{v}$ rámci této akce produkován, nebo byl jen reprodukován a stvrzován diskurz, který si „účastníci (herci i publikum) již prínesli“‘. S tímto zároveň souvisí další limit, totiž otázka, zda herci opravdu usilují o produkci nového diskurzu, nebo zda je jejich vystoupení možné vnímat jako sémantické konstrukce, kterými herci sami sebe spojují s určitými intepretacemi minulosti, čímž ospravedlňují svojí př́tomnost na oslavách a zcela tak naplňují ideu „herce“. ${ }^{12}$ Je také možné poukázat na Gouldenerovu kritiku námi zvoleného př́stupu. Tato kritika cílí na to, že se jedná o velmi utilitaristický př́stup, který je možné uplatnit na analýzu širokého spektra forem jednání (od sledování jednání konkrétního jedince přes veřejné události typů Slavností svobody až po analýzu základních organizačních principů společnosti). Tato tematická „rozkročenost“ pak logicky vede k tomu, že může svádět výzkumníky $\mathrm{k}$ interpretaci jimi pozorovaných událostí $\mathrm{v}$ podobně tematicky širokém okruhu (viz Gouldner 1970). K dalším kritickým reflexím tohoto prístupu srov. Blumer (1972) a Gouldner (1970).

\section{Představení a interpretace vybraných událostí Slavností svobody pohledem dramaturgické analýzy}

V této části se zaměříme na představení a interpretaci čtyř výše zmíněných událostí. Tyto akce byly vybrány zejména kvůli tomu, že jde o akce zajímavé pro politickou vědu, což je dáno jednak vysokou př́tomností politiků na těchto akcích, zároveň pak podobou přednesených projevư. ${ }^{13}$ Z tohoto hlediska se vybrané události jeví jako jasně vhodnější, než např́klad simulace bojových akcí na nádraží v Plzni-Koterově, koncerty na náměstí Republiky, model vojenského

12 Z pohledu politické vědy toto nepovažujeme za zásadní limit, protože velká část herců se událostí účastní zejména kvůli reprodukci svého statusu, respektive politického kapitálu.

13 Politici, zejména komunální, byli př́itomni i na dalších akcích, které ovšem nebyly vhodné $\mathrm{k}$ analýze - šlo např́iklad o kladení věnců u památníku na Chodském náměstí, které proběhlo v tichosti a zcela bez proslovů, nebo o pietní akt se zástupci amerického a belgického velvyslanectví, který se konal u památeční desky na schodišti v budově radnice a byl neveřejný. 
tábora nebo výstava vojenské techniky. Akce stručně charakterizujeme prostřednictvím tři dichotomií, které jsme nastínili v teoretické části. Každou z akcí popíšeme prostřednictvím rozdělení předních a zadních regionů, herců a diváků a konečně hlavních a vedlejších událostí. Zejména druhá dichotomie je velmi zajímavá, jelikož u některých z těchto akcí existuje po léta dodržovaný princip, který ze zástupců města se jich účastní, případně kteří vládní činitelé jsou zváni atd., což nám potvrdil i jeden ze zainteresovaných aktérů, s nímž jsme vedli rozhovor. Po představení akcí bude následovat interpretace diskurzivní produkce.

Poslední výše uvedená dichotomie je v tomto př́padě do jisté míry specifická, protože nahlédneme-li na celé Slavnosti svobody, které sestávaly z řady akcí propojených společnou tematikou, jako na jeden celek, můžeme všechny čtyři zmíněné akce jako takové označit za akce hlavní, jelikož přímým způsobem sloužily k oslavě konce války, osvobození Plzně, vzdání úcty padlým vojákům a podobně. $\mathrm{Na}$ rozdíl od naši interpretace významu událostí byl však pohled jednoho ze zainteresovaných aktérů výrazně odlišný. Ten v rámci oslav vymezil několik druhů akcí a důvodů jejich konání - v první řadě šlo o akce sloužící jako program a servis pro americké válečné veterány participující na osvobození, kterých se oslav každoročně účastní celá řada, a jejich rodinné př́íslušníky, dále o jakousi nostalgickou složku spojenou s činností military klubů (šlo o simulaci vojenského tábora, prrehlídky bojové techniky atd.) a nakonec o akce vedlejší a doprovodné (což byly jednak koncerty a zároveň protokolární část sestávající z proslovů, kladení věnců atd.). Ačkoli tuto protokolární část - at’ už vzdání památky prostřednictvím pietních aktů a kladení věnců nebo pronášení proslovi̊ majících reprodukovat určitý diskurz - považoval také za důležitou, podružnost těchto akcí odvozoval zejména ze skutečnosti, že zájem veřejnosti o tyto akce je mizivý. Zatímco průjezdu konvoje historických vozidel přihliželo zhruba dvacet až třicet tisíc lidí, závěrečnému vzpomínkovému aktu za př́tomnosti vysokých ústavních činitelů „pouze“ několik set lidí a pietnímu aktu na náměstí Míru věnovalo pozornost pouze několik desítek osob. Z naší analytické perspektivy ovšem jednoznačně o hlavní události jde, jelikož mají přímou vazbu na téma oslav a díky politickému charakteru událostí a pronášením projevů dochází k jasnému rámování předkládané situace a reprodukci určitého diskurzu. Z našeho pohledu jde o akce hlavní a podíváme-li se na každou z těchto akcí zvlášt', můžeme dále identifikovat různě znatelné rozlišení hlavních a vedlejších událostí v rámci každé $\mathrm{z}$ těchto akcí.

Linii týkající se (re)produkce politického diskurzu můžeme navázat poukazem na rozdílnost ve vnímání důležitosti událostí v rámci Slavností svobody. Z pohledu politické teorie jsme označili za hlavní události právě takové, které slouží k (re)produkci požadovaného diskurzu (viz výše). Pokud se pokusíme poskytnout interpretaci projevů, které na analyzovaných událostech zazněly, lze začít konstatováním, že projevy, které byly předneseny, můžeme považovat optikou analýzy diskurzu (srov. Fairclough 2004) za stavební kameny, které 
napomáhají k produkci a upevňování diskurzu požadovaného ze strany prítomných „herců“, tedy členů prítomného politického týmu.

Než prristoupíme $\mathrm{k}$ interpretaci dílčích vybraných událostí, shrňme stručně celý průběh Slavností svobody. V rámci námi pozorovaných událostí jsme nezaznamenali žádné snahy o symbolické narušování předkládaných definic a produkovaného diskurzu. Lze konstatovat, že předkládané situační definice ze strany politických týmů byly $\mathrm{v}$ souladu s očekáváním prítomných diváků, a obsah a forma diskurzivní (re)produkce ze strany účinkujících politických reprezentantů tak byly přihlížejícími vnímány jako legitimní (srov. Weber 1998). Z logiky věci byli na velké části událostí napojených na Slavnosti svobody př́tomni váleční veteráni, kteři se účastnili osvobozování Plzně. $\mathrm{Na}$ základě pozorování jsme ale nabyli dojmu, že jejich úlohu a funkci v rámci parciálních událostí můžeme interpretovat v intencích toho, že participující váleční veteráni plnili kromě jejich symbolické funkce také funkci určitých kulis. Jejich přitomnost lze proto vnímat tak, že představovali integrální součást - rekvizitu - divadelních představení, která byla $\mathrm{v}$ rámci Slavností svobody odehrávána. ${ }^{14}$

Největší pozornosti přhlížejících diváků se těšil průjezd vojenských vozidel centrem města. ${ }^{15} \mathrm{~V}$ naší perspektivě můžeme tuto akci označit jako podružnou událost, jelikož napomáhala $\mathrm{k}$ tomu, aby do místa konání akce přitáhla co největší počet diváků a nasměrovala tak jejich pozornost i $\mathrm{k}$ méně divácky atraktivním událostem, čímž de facto plnila roli podružné události v tom významu, v jakém o ní hovoří Erving Goffman (srov. 1966). Zajímavou roli v rámci této události (ale i některých ostatních) plnili distributoři vlajek. V rámci Slavností svobody byly distribuovány státní vlajky USA, České republiky a Belgie. ${ }^{16} \mathrm{~S}$ poukazem na to konstatujeme, že celkový průběh slavností můžeme považovat za vhodný prŕklad posilování uměle vybudovaných tradic, jak o tom hovoří Hobsbawm a Ranger v úvodní kapitole sborníku The Invention of Tradition (1992).

I přes to, že se jednalo ze své povahy o vedlejší událost, můžeme i zde nalézt určité symboly statusové reprodukce účastníků akce. Ty lze hledat v tom, že např́íklad v jednom z vozidel v průvodu seděl plzeňský zastupitel Petr Náhlík, př́padně $\mathrm{v}$ tom, že skoro na konci události byl umístěn balkón, na kterém se nacházel moderátor události a vybraní hosté; pod balkónem jsme zahlédli

\footnotetext{
${ }^{14}$ Naší interpretaci válečných veteránů jako specifických rekvizit můžeme ilustrovat např́ílad na tom, že jednou z dominantních akcí v rámci kulturního programu na Náměstí republiky byl zinscenovaný př́jezd válečných veteránů. Ti přijížděli na náměstí v dobových vozidlech a byli jmenovitě představováni moderátorem akce. Druhý př́klad můžeme spatřovat $\mathrm{v}$ tom, že na zahajovacím ceremoniálu byl ze strany politických představitelů teatrálně vítán a objímán zástupce veteránů.

15 Tzv. „Convoy of Liberty“ projíždějící dne 3. 5. 2015. Kolonu běžně tvoři kolem 150 vozidel, ve výročním roce 2015 jich bylo ovšem kolem 350, včetně aktivní techniky české a americké armády (Česká televize 2015).

${ }^{16}$ Belgická vlajka se ale netěšila velkému zájmu ze strany přihlížejících, protože byla z jejich strany často zaměňována za vlajku Německa („Nechápu, proč tady rozdávaji německý vlajky.“).
} 
politiky Marka Ženíška a Miroslava Kalouska. Analyticky relevantní bylo také samotné rámování této podružné události ze strany zainteresovaného aktéra, který hovořil o tom, že on osobně (jako reprezentant radnice a politik) vnímá tuto událost jako hlavní, která právě napomáhá tomu, aby Slavnosti svobody navštívil co největši počet účastníků, a naopak události, na nichž docházelo k reprodukci politického diskurzu, označoval až jako sekundární. Tímto došlo de facto $\mathrm{k}$ prohození role událostí $\mathrm{v}$ tom smyslu, $\mathrm{v}$ jakém je nahlížíme my perspektivou Ervinga Goffmana a jak je nahlíží zainteresovaný aktér.

Pokud hovoříme o vedlejších událostech navázaných na Slavnosti svobody, můžeme ještě stručně zmínit kontinuální expozici dobového kempu americké armády v Křižíkových sadech. Expozici dobového kempu navštěvovalo poměrně značné množství diváků, a bylo zajímavé zaměřit se na jejich reakce, které můžeme sumarizovat do dvou hlavních linií na základě četnosti jejich výskytu. První linie úzce souvisela stím, o čem budeme podrobněji pojednávat při interpretaci dílčích událostí - ze strany značné části přihlížejících docházelo k symbolickému propojování událostí spojených sosvobozením Plzně se současným mezinárodně-politickým vývojem. Konkrétně docházelo $\mathrm{k}$ tomu, že v rámci této linie reakcí byla ze strany pruihlížejících často stavěna paralela ke vztahu Ukrajiny a Ruska. K tomuto docházelo i v rámci oficiálních proslovi̊ (viz níže), a můžeme tak tvrdit, že jeden z (re)produkovaných diskurzů („Rusko je bezpečnostní hrozba pro Evropu'), byl ze strany přihlížejících přejat nebo stvrzen. Druhou linii častých reakcí ze strany přhlížejících pak můžeme spatřovat $\mathrm{v}$ tom, že docházelo k symbolickému propojování vztahu mezi USA a osvobozením a $\mathrm{k}$ reprodukci specifické mytopoezie týkající se toho, že USA (podle reakcí prihlížejících) představují určitý symbol svobody spojený jak s osvobozením Plzně, tak se současným kontextem („USA jsou symbolem minulé i současné svobody").

Než se přesuneme $\mathrm{k}$ interpretaci dílčích akcí a způsobu, jakým na nich docházelo k (re)produkci požadovaného diskurzu, můžeme konstatovat, že v rámci Slavností svobody jsme identifikovali dvě hlavní metafory, které se vinuly i v rovině diskurzivní produkce. Přijmeme-li pohled George Lakoffa a Marka Johnsona (2002: 16), že metafory v epistemologické a ontologické rovině „strukturují naše vnímání, myšlení a konání“, je možné konstatovat, že vykreslování Ruska jakožto hrozby pro evropskou bezpečnost a portrétování USA jakožto symbolu svobody představují stěžejní body rámující celkové vyznění Slavností svobody. Jak jsme již nastínili v závěru části a teoretickometodologickém konceptu, v silách dramaturgické analýzy jako takové není rozlišit, zda je daný diskurz produkován $\mathrm{v}$ rámci této události, nebo zda si účastníci daný diskurz osvojili již před započetím akce a na místě jej dále reprodukují a posilují. To znamená, že dramaturgická analýza může vést k opomenutí toho, že diskurz, respektive výše uvedené metafory jako součásti analyzovaného diskurzu, nemusely být ze strany přhlížejících přejaty, ale mohlo 
dojít $\mathrm{k}$ tomu, že byly sdíleny a do námi sledovaného kontextu tedy již byly přineseny a $\mathrm{v}$ něm veřejně manifestovány. Limitem zvoleného př́stupu je tak to, že jen složitě dokáže rozlišit zkušenosti (respektive názory, normy, hodnoty atd.), které si účastníci, tedy zejména diváci, přinesou s sebou, od těch, které si osvojí na místě. Přesto je ale tento př́stup při studiu diskurzu užitečný, jelikož z našeho pohledu nešlo pouze nebo primárně o to, zda je na akci vytvářený nový diskurs; důležité bylo i to, zdali dochází k jeho reprodukci.

\section{a. Zahájení Slavností svobody Plzeň za účasti válečných veteránů}

První námi analyzovanou událostí bylo „Zahájení Slavností svobody Plzeň za účasti válečných veteránư “ počáteční den slavností. Zahájení se odehrálo v Borském parku ležícím mimo centrum města. V parku byla rozmístěná vojenská technika, zejména dobová americká vozidla, organizovaná př́slušníky military klubů z různých zemí, př́tomná byla ale i jednotka americké armády. Stranou od této techniky se nacházelo pódium a několik stánků s občerstvením (př́ítomnost pódia i stánků tuto akci odlišovala od dvou následujících akcî). Tato akce probíhala v roce 2015 poprvé. Přední region byl tvořen zastřešeným pódiem, na kterém byly proneseny proslovy zástupců města a také jednoho z veteránů. Za součást tohoto regionu je možné považovat i řady židlí pod pódiem, které byly vyhrazeny právě pro veterány. Zadní region se nalézal těsně vedle pódia a byl dobře viditelný. Mezi hlavní aktéry odehrávající politické role $\mathrm{v}$ předním regionu této události můžeme počítat primátora města Martina Zrzaveckého a jeho prvního náměstka Martina Baxu, kteři pronesli proslovy, dále pak jednoho ze zástupců veteránů, který taktéž vystoupil. Kromě těchto politiků byli na akci př́tomni další politici lokální i celostátní (např́ílad náměstkyně primátora Eva Herinková, poslanci Marek Ženíšek [zvolený za Plzeň] a Miroslav Kalousek), kteří $\mathrm{v}$ průběhu akce postávali $\mathrm{v}$ zadním regionu nebo procházeli mezi návštěvníky, na akci ovšem nijak neparticipovali a ani nebyli oficiálně př̀edstaveni nebo přivítáni; nebylo je tak možné považovat za účinkující. V rámci třetí dichotomie byl hlavní událostí př́jezd amerických a belgických veteránů a jejich rodin $\mathrm{v}$ dobových vojenských vozidlech (veteráni byli v průběhu celé této události využíváni spíše jako rekvizity než jako účinkující17 ${ }^{17}$ ), dále pak pronesené proslovy a jejich přivítání, přičemž vše spojené s veterány bylo doprovázeno potleskem všech př́tomných, kterých dle našich odhadů bylo několik set, nejvíc ze všech sledovaných akcí (s výjimkou průjezdu konvoje historických vozidel). Tuto návštěvnost je možné přićitat jednak prrítomnosti veteránů, dále pak př́tomnosti bojových vozidel (a také občerstvenî), což potvrzuje výše zmíněný pohled zainteresovaného aktéra, který za hlavní považoval akce spojené s veterány a historickými vozidly, a to právě kvưli většímu zájmu návštěvníků.

${ }^{17} \mathrm{~S}$ výjimkou jednoho z nich, který pronesl proslov. 
První vystoupil primátor města Plzně Martin Zrzavecký, jemuž jakožto „hostiteli“ oslav připadla čest pronést zahajovací proslov Slavností svobody. Ten zahájil živelným gestem (respektive pokud přijmeme argumentaci Ervinga Goffmana, můžeme tvrdit, že se jednalo o předem připravený herecký akt evokující pocit spontánnosti), a sice že si odložil stranou podklady s připraveným projevem a začal hovořit spatra, což nezapomněl publiku oznámit. V projevu diskurzivně propojil konec druhé světové války s konstatováním, že od osvobození Plzně (a následného konce války) nebyla v Evropě přes sedmdesát let válka (respektive že Evropa žije právě díky Američanům již sedmdesát let v míru). ${ }^{18}$ Toto konstatování se opakovalo i v dalších projevech Martina Zrzaveckého. Kromě obvyklých a očekávaných frázi ${ }^{19}$ nezaznívala v projevech na této události žádná další vyjádření, na jejichž základě bychom mohli identifikovat proces diskurzivní produkce. Co se ale týče reprodukce statusů prítomných hostů, je vhodné poukázat na to, že zahajovací ceremoniál Slavností svobody, který „otevřel“ svým projevem primátor Plzně Martin Zrzavecký, mohl vést $\mathrm{k}$ (re)produkci jeho statusu právě tím, že byl protokolárně situován do role hostitele celé několikadenní události. Z hlediska tvorby a rozšiřování diskurzu požadovaného ze strany účinkujících byly zajímavější následující tř́ události.

\section{b. Odhalení pomníku generála G. S. Pattona}

$\mathrm{V}$ ten samý den proběhla i druhá sledovaná akce, „Odhalení pomníku generála G. S. Pattona“"v centru Plzně v nově upraveném parkovém prostoru, v sousedství budovy Divadla Josefa Kajetána Tyla. Tato akce byla z pohledu prítomných politiků i pronesených proslovů daleko zajímavější, zájem publika byl však daleko nižší než u první zmiňované akce. Ani tato akce v dřívějších ročnících neproběhla, nelze tudíž vysledovat jakékoli zvyklosti určující relevanci, pořadí a rozestavění účinkujících. Přední region byl tvořen prostranstvím před pomníkem. Zadní region, ve kterém se naprríklad prripravovali lidé ke kladení věncư, byl opět umístěn viditelně ihned vedle regionu předního. Pomyslné hlediště tvořilo celé okolí předního a zadního regionu, od nichž bylo oddělené červenobílou páskou. $\mathrm{Na}$ akci participovali mimo jiné zástupci policie včetně policie městské, dále pak zástupci Sokola, armádní kapela a př́tomni byli i někteř́i veteráni (ti všichni, $\mathrm{s}$ výjimkou složek státního aparátu, opět $\mathrm{v}$ roli rekvizit). Z př́tomných členů politického týmu byli jmenovitě představeni primátor města Zrzavecký, místopř̀edsedkyně Senátu Miluše Horská, dále poslanec Evropského parlamentu

\footnotetext{
18 Pokud se podíváme na události navázané na rozpad Jugoslávie, př́padně na současný konflikt na Ukrajině, můžeme hovořit o tom, že dané prohlášení bylo spíše politickým argumentačním gestem než vyjádřením nekontroverzního faktu.

19 Za obvyklé a očekávané fráze označujeme takové, které se týkaly přivítání veteránů a návštěvníků akce, poděkování za osvobození a podobně.
} 
Jiří Pospísilil (pochází z Plzně), jeden z náměstků hejtmana a také přítomný vnuk generála Pattona. Další politici byli př́edstaveni nejmenovitě („vítáme prútomné členy Poslanecké sněmovny a Senátu PČR"). Mezi ně patřila např́iklad senátorka Milada Emmerová, která se nacházela přímo v části předního regionu, kde probíhal slavnostní akt, dále senátor a starosta jedné z plzeňských městských částí Lumír Aschenbrenner nebo poslanci Marek Ženíšek a Miroslav Kalousek, kteři se sice nacházeli $\mathrm{v}$ páskou odděleném prostoru, ovšem mimo hlavní dění. Další prŕtomní politici nebyli představeni ani přivítáni - např́íklad zcela stranou mimo oba zmíněné regiony stál na okraji hlediště bývalý plzeňský primátor Pavel Rödl. Proslovy pronesli zejména primátor města, místopředsedkyně Senátu, dále pak zástupkyně americké ambasády, vnuk generála Pattona a nakonec jeden $z$ autorů pomníku. V souvislosti se třetí dichotomií můžeme konstatovat, že obě části události - jak odhalení pomníku a kladení věnců, tak pronesení proslovů lze považovat za události hlavní.

Jak je z výše uvedeného patrné, odehrávalo v rámci slavnostního odhalení pomníku generála G. S. Pattona své politické role značné množství politických představitelů. Stejně jako u předchozí události jsme i zde toho názoru, že jmenovité představování ${ }^{20}$ relevantních herců můžeme vnímat jako nástroj, který slouží k sémantickému zvyšování (resp. udržovánî) statusového postavení takto představovaných aktérů politického spektáklu. I nejmenovitě uvítaní členové politického týmu se nacházeli ve VIP prostoru, který můžeme považovat za jeden z předních regionů této události, jelikož samotnou př́tomnost těchto politických představitelů lze vnímat jako součást divadelního představení politického karnevalu Slavností svobody.

$\mathrm{Na}$ této události také zazněla věta z názvu článku, kdy místopředsedkyně senátu hovořila o tom, že Plzeň je „nejameričtější město v Evropě“. Na toto prohlášení sémanticky navázala zástupkyně amerického konzulátu, která prohlásila, že Česká republika je pevným americkým spojencem v rámci Severoatlantického spojenectví. Toto propojování České republiky a Spojených států jakožto pevných partnerů se objevovalo v proslovech pravidelně. Zmínil se o tom např́klad i Martin Baxa, a to $\mathrm{v}$ kontextu skutečnosti, že Plzeň je proamerické město a Česká republika pro Spojené státy klíčový spojenec.

\section{c. Pietní akt u památníku Obětem 2. světové války a padlým československým a spojeneckým letcuim}

\footnotetext{
${ }^{20}$ To je samozřejmě projevem etikety a reifikací ceremoniálních procedur. A to, který politický reprezentant bude na jaké dílčí akci př́tomen, vychází podle jednoho ze zainteresovaných aktérů z tradice - tedy, že osoby zaujímající určité posty se tradičně objevují na partikulárních složkách slavností (např. primátor na zahájení, náměstek na pietní akci na Náměstí Míru, vysocí ústavní činitelé na pietní akci u pomníku „Díky, Ameriko!“” a podobně).
} 
Třetí sledovanou akcí byl „Pietní akt u památníku Obětem 2. světové války a padlým československým a spojeneckým letcům" na námětí Míru v Plzni. Tato událost měla dvě části - první (hlavní) spočívala v pietním aktu u památníku v centru náměstí Míru. Poté byly položeny věnce ještě u památníku padlým letcům, který je umístěn v parku na okraji náměstí; vzhledem k marginálnímu významu se této části věnovat nebudeme.

Mezi námi analyzovanými akcemi je tato první, která se opakuje každoročně a je tudíž možné vysledovat i jisté zvyklosti. Tou hlavní je nepř́itomnost primátora města. Ačkoliv jsou celé slavnosti organizovány př́ímo městem, tato akce probíhá v režii Českého svazu bojovníků za svobodu a dle informace poskytnuté zainteresovaným aktérem jde o akci, která je vedením města považována za podružnou, z čehož vyplývá mimo jiné právě nepř́itomnost primátora - město bývá na tomto pietním aktu zastoupeno jeho náměstkem či náměstky. Stejně tak je součástí tradice prítomnost zástupců leteckých sil a také Sokola a Svazů bojovníků za svobodu, kteří (např́ílad členové Sokola ve stejnokrojích a s prapory) dotvářeli kulisu události, čímž opět (společně s veterány) plnili funkci rekvizit.

Podíváme-li se na rozlišení regionů, je v tomto př́padě velmi jednoduché přední region byl tvořen prostranstvím před památníkem, kde probíhaly proslovy a kladení věncủ. Na okraji tohoto regionu hrála Kapela 35. pěšího pluku Plzeň. Zadní region, ve kterém postávali političtí představitelé v době, kdy se neúčastnili proslovů nebo kladení věnců, se nalézal bezprostředně vedle regionu předního a nenucené a uvolněné chování politiků v tomto regionu (telefonování, vzájemné bavení atd.) tak bylo príhlížejícím dobře viditelné. Nalézalo se dokonce ve stejném zorném úhlu jako region přední. Hlediště tvořily řady plastových laviček uprostřed náměstí, přední lavičky byly vyhrazeny pro veterány. Přejdeme-li k druhé dichotomii, za hlavní účinkující můžeme označit několik členů politického týmu. Šlo zejména o trojici zástupců plzeňského magistrátu - prvního náměstka primátora Martina Baxu a dále řadové náměstky Pavla Kotase a Evu Herinkovou. Zde je zajímavé zmínit, že výsadní postavení prvního náměstka bylo stvrzeno např́klad skutečností, že k pietnímu aktu náměstci přistupovali ve striktním pořadí: Jako první šel Martin Baxa a za ním ve dvojici zbylí náměstkové, stejně tak Martin Baxa jako jediný z př́tomných náměstků přednesl projev. Další projev přednesl náměstek hejtmana Plzeňského kraje mimo jiné pro oblast Plzeň jako Evropského hlavního města kultury 2015 (a zároveň starosta Tachova) Jiří Struček. Pietního aktu se $\mathrm{v}$ roli vedlejších herců účastnili i další političtí představitelé, naprŕíklad senátor za obvod Cheb Miroslav Nenutil nebo náměstek hejtmana Plzeňského kraje Ivo Grüner, poslanec Marek Ženíšek a někteří další. Policii $\mathrm{v}$ roli vedlejších herců zmíníme (stejně jako v případě dalších sledovaných akcî) v samostatné části. V rámci třetí dichotomie můžeme konstatovat, že hlavní událostí byl pietní akt (kladení věnců) a pronesení proslovů, vedlejší událostí pak živá hudba doprovázející událost. 
Obdobně jako předchozí události je možné tuto událost interpretovat v intencích oslav „antitotality“. Jednak bylo zdůrazňováno to, že ukončení druhé světové války vedlo ke svržení totalitního režimu, který však byl v Československu nahrazen jinou totalitou - komunistickou. Toto směšování komunistického režimu s totalitním režimem, byt' po celé trvání jeho existence jistě totalitním nebyl (srov. Linz 2000), je $\mathrm{v}$ české společnosti a v českých médiích poměrně běžné. Pietního aktu na náměstí Míru se účastnilo poměrně malé množství přhlížejících, a to navzdory skutečnosti, že zde bylo přítomné značné množství politických reprezentantů (jak v roli herců, tak v roli přhlížejících). Na začátku akce byli jmenovitě představení př́tomní poltičtí reprezentanti (z nichž ale byla většina pro průběh ceremonie naprosto irelevantní, protože se na ní nepodíleli), což opět můžeme interpretovat $\mathrm{v}$ intencích zvyšování jejich symbolického statusu. Událost zahájil Martin Baxa, který ve svém proslovu diskurzivně propojoval celebrované události se současnými bezpečnostními výzvami pro Evropu, prričemž $\mathrm{v}$ tomto bezpečnostním diskurzu rámoval jako jednu z akutních hrozeb pro Evropu Rusko a jeho jednání. Konkrétně poukázal na skutečnost, že „suverénní území Ukrajiny je jejím sousedem, putinovským Ruskem znovu mocensky oklešt’ováno a rozdělováno. Můžeme se sice donekonečna dohadovat o tom, co je př́ícinou tohoto konfliktu, avšak faktem, který se nedá obejít, je to, že suverénní Ukrajina př́šla zřejmě navždy o část svého území, poloostrov Krym, a její další, východní část je v podstatě anektována. ${ }^{\text {‘21 }}$

Jakožto další stavební kameny diskurzu produkovaného v rámci této události můžeme vnímat i varování před tím, abychom nezapomněli na události z roku 1939 a 1968. Dále také skutečnost, že ve svém projevu poukázal na to, že o svobodu a demokracii musíme stále bojovat. Toto vymezování ve vztahu $\mathrm{k}$ Rusku bylo patrné i u některých príhlížejících, kteří se mezi sebou bavili o tom, že ,je škoda, že jste [Američané] nedojeli až do Prahy“. V obdobné linii byla vedena i argumentace ve speciálu České televize věnovanému Slavnostem svobody, kde jeden z prŕtomných historiků hovořil o tom, že Američané přinášeli svobodu, zatímco Rusové byli motivováni imperialistickými pohnutkami (Česká televize 2015).

Dalším vystupujícím byl Jiří Struček, jehož projev jsme vnímali jako pietnější: $\mathrm{v}$ rámci jeho proslovu opakovaně zaznívalo poděkování veteránům, respekt $\mathrm{k}$ obětem a podobně, a $\mathrm{z}$ hlediska (re)produkce diskurzu tak tento projev označujeme spíše jako ceremoniální. Posledním aktérem tohoto ceremoniálu byl př́slušník Svazu bojovníků za svobodu, který kromě ceremoniálních a pietních záležitostí hovořil o tom, že Plzeň opakovaně blokuje výstavbu nového památníku obětem 2. světové války a padlým letcům, což lze vnímat jako určité narušení „týmové hry“ účinkujících. To může podle Goffmana představovat potenciální

\footnotetext{
${ }^{21}$ Následně Martin Baxa na svém facebookovém profilu umístil fotografii z akce s komentářem, že dnes v rámci Slavností svobody promluvil o ruském nebezpečí pro Evropu.
} 
problém při předkládání situačních definic ze strany hereckého týmu, jelikož se tak může narušovat argumentační a kognitivní ucelenost celé akce v očích přihlížejících. ${ }^{22} \mathrm{~V}$ př́padě týmových prezentací je klíčové, aby všichni členové týmu dodržovali předem daná schémata a dávali si pozor na to, aby nepodali takový výkon, jenž by měl destruktivní dopad na předkládanou definici situace (Goffman 1999: 40).

\section{d. Vzpomínkový akt u památníku „Díky, Ameriko!““}

Poslední akce, vzpomínkový akt u památníku „Díky, Ameriko“, měla ze všech sledovaných událostí největší počet účinkujících, tedy členů politického týmu. Akce u tohoto památníku, který se nachází v centru města na rušné křižovatce Klatovské tř́ídy a Americké, probíhá každoročně. Pravidelně dochází k obdobným dopravním omezením (uzavře se jeden pruh Klatovské, na který zejména prrijíždí autobus s veterány, a celá horní část Americké, kde jednak stojí diváci a zároveň zde parkují auta hostů a řečníků, policie a podobně). Každoročně také dochází $\mathrm{k}$ vystoupení řady politických př́edstavitelů, at' již zástupců města, kraje nebo vlády (pravidelně se účastní některý z ministrů, př́padně ministři pocházející z Plzně a okolí - vzhledem k sedmdesátému výročí se roku 2015 výjimečně účastnil předseda vlády), obou parlamentních komor (pravidelně se účastní předseda alespoň jedné $\mathrm{z}$ nich, dále pak poslanci a senátoři zvolení za region) či amerického velvyslanectví. Akce probíhala na prostranství v blízkosti památníku; celá oblast, ve které probíhala ceremonie (jak přední, tak zadní region), byla oddělena páskou, za kterou neměli diváci př́stup ( $\mathrm{s}$ výjimkou novinářů, príbuzných amerických a belgických veteránů a dalších hostů). Předním regionem, tedy jevištěm, bylo zejména vybudované kryté podium, na němž (opět jako rekvizity) seděli veteráni a stáli političtí představitelé, kteři se s projevy stř́dali u mikrofonu. Druhou částí jeviště byl prostor okolí památníku, kde byly kladeny věnce. Zadní region, který se nalézal v prostoru za krytým podiem, byl pro část hlediště (při čelním pohledu na podium) zakrytý, ale z jiných částí dobře viditelný. Jako zadní region do velké míry fungovala i část podia, jelikož bylo patrné uvolněné chování představitelů ve chvilích, kdy se prŕmo nezapojovali do dění. Mezi herci bychom nalezli zejména politické př́edstavitele. Pořadatelem byli jmenovitě představeni premiér města Plzně Martin Zrzavecký, předseda Poslanecké sněmovny Jan Hamáček, předseda vlády Bohuslav Sobotka, první místopředseda Senátu Přemysl Sobotka, ministr vnitra Milan Chovanec (který byl zvolený za Plzeñ), ${ }^{23}$ ministr obrany Martin Stropnický, ministr kultury Daniel

\footnotetext{
${ }^{22}$ Linie vzájemného vymezování mezi představiteli města a zástupcem Svazu pokračovala i v rámci provedených rozhovorů se zainteresovaným aktérem, který projevy tohoto člena Svazu označoval za „sáhodlouhé a nudné“.

${ }^{23}$ Nicméně ministr Chovanec $\mathrm{v}$ danou chvíli na podiu prítomen nebyl, což doprovázely rozpačité pohledy a komentáře dalších politických představitelů. Na pódiu tak docházelo k výše zmíněnému
} 
Herman, velvyslanec USA Andrew Shapiro, velvyslankyně Belgie Françoise Gustin, velvyslanec Slovenska Peter Weiss a další zástupci diplomatického sboru; dále nejmenovitě členové obou parlamentních komor, opět jmenovitě poslanec Evropského parlamentu Jiři Pospíšil, hejtman Plzeňského kraje Václav Šlajs, plzeňský biskup František Radkovský, rektor Západočeské univerzity v Plzni Miroslav Holeček, zástupce kanceláře prezidenta republiky (nejmenovitě), zástupci Ústavního soudu (nejmenovitě), dále zástupci ozbrojených sil, členové rady Plzeňského kraje, náměstci primátora Plzně a členové rady města Plzně (všichni nejmenovitě). S proslovem jako první vystoupil primátor města, po něm předseda Poslanecké sněmovny, předseda vlády, první místopředseda Senátu, dále americký velvyslanec, hejtman Plzeňského kraje a zástupce amerických veteránů. Poté proběhlo kladení věnců. $V$ roli vedlejších aktérů působila řada policistů, zástupců armády, Sokola atd. $\mathrm{V}$ rámci třetí dichotomie můžeme konstatovat, že hlavními událostmi byl vzpomínkový akt a pronesení proslovi̊, vedlejšími událostmi vystoupení armádního orchestru a další atrakce pro diváky, např́iklad přelet armádních letadel.

Tato událost představuje asi nejoficiálnější akci proběhnuvší v rámci Slavností svobody. Tomu odpovídala i prítomnost vysokých ústavních činitelů a znatelná přítomnost složek státního aparátu. Místo konání bylo ze všech stran ohrazeno a bylo tak neprrístupné přihlížejícím. Oproti předchozí analyzované akci můžeme hovořit o tom, že zde byl jasně vymezený specifický „mocenský region“, do kterého měli prrístup pouze aktivní účastníci politického představení (herci a rekvizity). Diváci byli z tohoto prostoru vyjmuti. Stejně jako na předchozí události i zde byli jmenovitě vítáni př́tomní účastníci, kteří měli vyhrazené místo na jevišti, a z nichž naprostá většina ale neparticipovala formou projevu a jejich participace spočívala pouze $\mathrm{v}$ prítomnosti na jevišti. Jejich jmenovité představení opět mohlo vést ke zvyšování jejich symbolického statusu. Díky tomu, že jejich participace byla omezena na pouhou účast, je lze považovat za specifické rekvizity sehrávaného divadelního představení. Z přednesených projevi̊ nás nejvíce zaujal projev Andrewa Shapira (a to jak z hlediska formy, tak obsahu) a Bohuslava Sobotky. Andrew Shapiro poukázal na to, že bychom měli mít na paměti, že američtí vojáci byli z naprosté většiny mladí kluci, kteří byli daleko od domova a príjeli osvobodit malou zemi, která byla z jejich pohledu velmi daleko. Neprrišli proto, aby zemi obsadili, ale osvobodili. To dle naší interpretace stavělo subtilní paralelu k dění na Ukrajině, kdy poselstvím tohoto projevu byla de facto teze, že by zbytek Evropy neměl ignorovat to, co se děje na Ukrajině. Evropa by měla být jednotná, a to nejen v otázce Ukrajiny. Po dramaturgické stránce zahájil Shapiro celou akci tím, že sestoupil jako jediný z prítomných herců k publiku a začal rozdávat odznáčky s americkou vlajkou, což sklidilo u př́tomného

uvolněné chování ze strany aktérů, které by v předním regionu dle Goffmana (1999) nemělo být př́tomno. 
obecenstva velmi kladný ohlas. Shapirovo vystoupení tak bylo v souladu s metaforou o tom, že USA jsou symbolem svobody, a to jak z historické perspektivy, tak i v současném kontextu.

Bohuslav Sobotka se ve svém projevu snažil diskurzivně mírnit sémantické vykreslování Ruska jako bezpečností hrozby pro Evropu (viz předchozí projevy a reakce značné části přihlížejících). Hovořil o tom, že bychom neměli zapomínat, že se bojů o osvobozování Československa aktivně zapojovali i ruští a ukrajinští vojáci (což zmínil i první místopředseda Senátu Přemysl Sobotka). Toto prohlášení s ohledem na vyznění plzeňských Slavností svobody zaznělo vůbec poprvé.

Z hlediska formy nás také zaujal projev Jana Hamáčka, který jako jediný $\mathrm{z}$ př́tomných politických herců hovořil na prvním místě směrem $\mathrm{k}$ válečným veteránům $\mathrm{v}$ angličtině, čímž byl de facto jediným účinkujícím, který nevyužíval př́tomné veterány jako rekvizitu, ale jako hlavní subjekt slavností. Ve svém projevu pokračoval ve vymezování se vưči minulému režimu, když konstatoval, že Plzeň ,,[...] coby největší město osvobozené americkou armádou bývala orgánům minulého režimu apriorně podezřelá. “24 Americké tanky přivezly do Plzně svobodu, nicméně trvalo desítky let, než se jejich odkaz naplnil. Stejně jako jiní (Američané) pomáhali na konci války Československu, bude nyní Česká republika jako pevný článek NATO pomáhat ke svobodě jiným.

Jako poslední ze členů politického týmu vystoupil hejtman Plzeňského kraje Václav Šlajs, který poukázal zejména na důležitost euroatlantických struktur. „Dnes žije vyspělá Evropa, Českou republiku nevyjímaje, sedmdesát let v míru. Toto je zásluha evropské integrace a my Češi máme zajištěnou v historii největší bezpečnost díky začlenění do euroatlantických struktur - NATO a Evropské unie.“ Dále zdůraznil, že v současném komplikovaném světě ovšem není mír nic samozřejmého - vojenské konflikty vznikají tam, kde nefungují sociálně ekonomické systémy, tam, kde není svoboda a demokracie nebo kde existuje náboženská, národní nebo rasová nesnášenlivost. V závěru projevu poděkoval americkým osvoboditelům. ${ }^{25}$

Posledním, co nás zaujalo, byl fakt, že př́tomní herci poměrně rychle a neobratně vystupovali ze svých rolí, čímž mohli snížit celkové vyznění tohoto vzpomínkového aktu. Pokud přijmeme Goffmanovo tvrzení, že účinkující mají sklony nabízet pozorovatelům dojem, který je různými způsoby zidealizovaný

\footnotetext{
${ }^{24}$ Skutečnost, že byla Plzeň osvobozena americkou armádou, nebyla součástí oficiální režimní „pravdy“, obdobné slavnosti tedy neprobíhaly. Skutečnost, že se slavnosti v polistopadovém období konají v poměrně velkolepém pojetí, přičítal jeden ze zainteresovaných aktérů právě tomu, že se osvobození před rokem 1989 veřejně oslavovat nesmělo.

25 Toto poděkování, stejně jako řada dalších konstatování v průběhu jeho proslovu, je částečně zarážející vzhledem ke skutečnosti, že RSDr. Václav Šlajs býval za komunistického režimu politicko-ideologickým pracovníkem armády, což dalo vzniknout kontroverzím a protestním peticím při jeho zvolení do funkce hejtmana.
} 
(1999: 36), je možné konstatovat, že vizuální přeplněnost pódia politickými herci a zejména rozdíl v jejich „odehrávání situační definice a „odehráváni“" sebe sama mohl vést $\mathrm{k}$ tomu, že zidealizovaný dojem z vystoupení bude ve výsledku snížen. Narážíme zejména na to, že v průběhu ceremoniálu se př́tomní herci, kteří zrovna „neodehrávali“" své role u mikrofonu, mezi s sebou bavili a nedodržovali tak etiketu této akce. Nejvíce patrné to bylo v okamžiku, kdy zazněla státní hymna. Ve chvíli, kdy začala hrát hymna (nejprve americká, poté česká), se všichni herci na pódiu (resp. v mocenském regionu jako celku) „přepnuli““ do ceremoniálního módu (přestali mezi sebou komunikovat, nahlížet do mobilních telefonů). Jakmile ale hymna skončila, tak se opět mezi s sebou začali bavit, sledovat tablety a podobně, čímž opět vystoupili ze svých odehrávaných rolí.

\section{Organizační linie Slavností svobody}

Pokud se posuneme od linie diskurzivní produkce $\mathrm{k}$ dalšímu záměru našeho textu, pokusíme se reflektovat, jakým způsobem mohou veřejné události typu Slavností svobody sloužit $\mathrm{k}$ tomu, že jejich prostřednictvím napomáhají státní aparáty k utváření svého obrazu jakožto garantů bezpečnosti „spořádaných občanư“ tedy príhlížejících těchto akcí. V rámci událostí typu Slavnosti svobody se složky státního aparátu soustředí na zachovávání veřejného pořádku a ochranu bezpečnosti přítomných prihlilízejících. Tuto organizační linii jsme zahrnuli proto, že je nedílnou součástí Slavností svobody a toho, jakým způsobem na tyto slavnosti nahlížíme. Podstatné je nejen organizační zajištění a jeho pojetí jako součásti hraného představení s policisty $\mathrm{v}$ roli vedlejších herců, ale také reprodukce požadovaného diskurzu.

Nejsilnější přítomnost složek státních aparátů byla na událostech „Convoy of Liberty“ a na vzpomínkovém aktu poslední den slavností. U ostatních akcí byly tyto složky státního aparátu zastoupeny spíše sporadicky (viz výše v části představující analyzované akce) a na většině akcí byla př́tomna jedna hlídka městské policie, která ji monitorovala (většinou v rámci rutinní pochůzkové činnosti). První výraznější policejní přítomnost jsme zaznamenali až v pozdních odpoledních hodinách na kulturních akcích na náměstí Republiky, kde se vyskytovali prŕslušníci městské i státní policie. Výrazná policejní př́tomnost byla na události „Convoy of Liberty“. Př́slušníci policie byli na akci přítomni už zhruba hodinu před jejím začátkem. Jednalo se zejména o dopravní policisty, kteří na místě řídili uzávěru silnice a dopravní opatření. Poté, co konvoj vyrazil, jsme se začali přesouvat jeho směrem. Se zmenšující se vzdáleností od centra města se začala policejní př́tomnost zvyšovat. Kromě dopravní policie zde byly prrítomny i klasické hlídky státní a městské policie. Zhruba v polovině trasy průvodu (u náměstí T. G. Masaryka) byly postavené železné bariéry oddělující účastníky konvoje od prìhlížejících. Toto souvisís tím, že bylo třeba vytyčit jasnou 
hranici mezi týmem „hercư“, kteří sehrávali svá představení, a přihlížejícími akce, pro které bylo toto představení určeno (srov. Goffman 1999). Od tohoto bodu směrem k začátku konvoje žádné zábrany oddělující konvoj od přihlížejících nebyly. To je možné nahlížet jako další opatření vedoucí k produkci bezpečnosti jedinců př́tomných na této události, poněvadž v tomto bodě velmi razantně narostl počet přihližejících (a ruku v ruce s tím i počet příslušníků státní a městské policie).

Pietní akce 5. května se účastnilo přibližně 150-200 diváků. S ohledem na to (a také na skutečnost, že na této události participovaly lokální politické elity) zde byla výrazná policejní přítomnost. $V$ průběhu akce jsme si všimli smíšených hlídek státní a městské policie, jež pravidelně obcházely prostory pietní události. Dále byli na akci př́tomni př́slušníci dopravní policie, $\mathrm{v}$ zadním regionu této akce ( $\mathrm{v}$ prostorech za objektem památníku, které nebyly z hlediště vidět) se nacházeli př́slušníci městské policie Plzeň v zásahovém vybavení. Mezi přihlížejícími se také pohybovali minimálně dva policisté v civilu, kteří monitorovali jejich jednání.

Nejdůležitější oficiální akcí v rámci Slavností svobody byl pietní akt u pomníku na Americké třídě, jenž ukončoval několikadenní slavnosti. Oficiálnímu charakteru akce (na niž byly př́tomny státní politické elity) odpovídala i přijatá bezpečnostní opatření. Celý prostor konání akce byl vyloučen z dosahu veřejnosti a byl zde určen specifický „mocenský region“, kde se nacházely prrítomné politické elity. Tento prostor byl zevnitř hlídán kombinovanými hlídkami státní a městské policie a ochrannou službou politiků. Kvůli tomu, že tato akce vedla k dopravním omezením na dvou frekventovaných komunikacích, nacházeli se zde i př́slušníci dopravní policie. $\mathrm{Na}$ zajištění bezpečnosti se podílely také kombinované hlídky nacházející se mimo uzavřený „mocenský region“. Kromě klasických policejních hlídek zde byly prrítomny i minimálně dvě hlídky policistů $\mathrm{v}$ civilu, kteří monitorovali jednání pruihlížejících a kontrolovali podezřelé formy chování. Když jsme se zaměřili na činnost těchto složek, všimli jsme si toho, že jejich pozornost je věnována faktorům, které na ně působily podezřele. Na podežrelé jednání upozorňovaly uniformované př́slušníky složek státního aparátu („Ten chlapík vzadu s igelitkou, ted’ jde od nás, jděte ho zkontrolovat.").

Logiku jednání týmu státních aparátů $\mathrm{v}$ rámci tohoto druhu veřejných událostí nám objasnil i rozhovor se zainteresovaným aktérem, který hovořil o tom, že „opatření mají samozřejmě preventivní nádech. Musíme dát víc lidí do ulic, aby se prostě nekradlo, aby se nic neničilo, aby se zabránilo dopravnímu kolapsu. $\mathrm{S}$ tím vším se musí počítat. 'Takže to je v podstatě taky prevence - at' dopravní, nebo prevence kriminality, nějakejch drobnejch krádeží.“ „Ve velkým množství lidí si nevšimnete, že vás tam někdo okrádá. Tak je potřeba, aby ti četníci tam chodili a dělali tu kulisu toho úřadu, který to tam dohlíží. "Tým státních aparátů se na akcích tohoto typu snaží vytvořit „tu iluzi těch modrejch lidí, že jsou všude vidět.“ Toto jednání má preventivní charakter a lze ho vnímat jako jeden z faktorů 
odpovídajících snaze o konstrukci percepce státních aparátů jakožto ochránců bezpečnosti přihlížejících na veřejných akcích. Jeden ze zainteresovaných aktérů se k problematice nasazování složek státních aparátů na tento typ akce vyjádřil v tom smyslu, že konkrétní zajištění události je plně v jejich gesci, ale že se jedná o taková opatření, která nemají vliv na strukturu a dramaturgii plánovaných událostí. Pro státní aparáty představují Slavnosti svobodu a na ně navázaná opatření více méně rutinní činnost.

\section{Namísto závěru - propojení dílčích interpretačních linií}

Jak již bylo zmíněno, v textu jsme se snažili interpretovat plzeňské Slavnosti svobody ve třech dílčích liniích. Konkrétně se jednalo o to, jakým způsobem mohlo na těchto veřejných událostech docházet $\mathrm{k}$ (re)produkci požadovaného diskurzu ze strany politického týmu. Dále jsme se zaměřli na to, jakými konkrétními praktikami si mohli př́tomní političtí herci zvyšovat svůj sociální status. Poslední linie směřovala $\mathrm{k}$ interpretaci toho, jakým způsobem mohou takovéto veřejné události sloužit $\mathrm{k}$ navozování obrazu státních aparátů jakožto ochránců bezpečnosti přihližejících, a tím tak upevňovat svoji legitimitu v očích veřejnosti.

V textu jsme se snažili dále poukázat na fakt, že i přes to, že sémanticky a diskurzivně byla vyzdvihována úloha válečných veteránů, ve skutečnosti na ně bylo možné nahlížet spíše jako na rekvizity a součásti představení, než jako na subjekty oslav. Z organizačního hlediska jsme se také zaměrili na to, že při výběru politických herců na parciálních událostech podléhá tento výběr ustáleným postupům a odvíí se mimo jiné od pozice představitelů v rámci hierarchie vedení města (či jiných úrovnî), čili od politického statusu. Účast a vystoupení na akci pak tento status dokáže dále zvyšovat či upevňovat. Slavnosti svobody můžeme nahlîžet jako událost, která napomohla 1) k reprodukci legitimity státních aparátů; 2) ke konstrukci nebo rozšiřování požadovaného diskurzu; a 3) ke zvyšování nebo upevňování symbolických statusů herců.

Vrátíme-li se k metaforám uvedeným v úvodu textu („Rusko je bezpečnostní hrozba pro Evropu“ a „USA jsou symbolem minulé i současné svobody"), je patrné, že $\mathrm{v}$ rámci interpretativní části analýzy se tyto metafory ukázaly jako platné a jako něco, co bylo reprodukováno všemi/většinou prŕtomných členů politického týmu (byt' je prri tomto konstatování třeba připomenout limity, které vyplývají ze zvoleného teoreticko-metodologického rámce - viz výše). ${ }^{26}$ Tyto metafory často splývaly dohromady a Rusko bylo představováno jako potenciální bezpečnostní problém, který může a má být řešen pouze za spoluúčasti USA, tedy v rámci pevného euroatlantického spojenectví. Stejně jako byla v souvislosti

${ }^{26}$ Jeden ze zainteresovaných aktérů dokonce $\mathrm{v}$ rámci rozhovoru sdělil, že reprodukci diskurzu Ameriky jako osvoboditele a šiřitele míru a pozitivních hodnot považuje za svoji povinnost politického činitele. 
s koncem války zdůrazněna rozdílnost amerických vojáků, kteří přicházeli jako osvoboditelé, a vojáků sovětských, kteří byli nástrojem Stalinovy imperialistické politiky, je za pomoci obdobné dichotomie interpretována i současná americká a ruská zahraniční politika - ruské intervence jsou stále rámovány jako projev imperialismu, ty americké jako šíření míru a svobody.

Zajímavou otázkou při výzkumu založeném na dramaturgické analýze je také to, zda ze strany pořadatelů proběhlo představení dle předem přpravovaného scénáře, tedy zda nedošlo k určitým dramaturgickým selháním. Z výše uvedeného je patrné, že týmy herců i přhlížejících v podstatě sehrávaly očekávané role. Připravená dramaturgická linie byla zachována i díky tomu, že ze strany publika nedošlo k žádnému zásadnímu pokusu o narušení scénáře a herci předkládané situace. Drobná dramaturgická selhání projevující se např́ílad výše zmíněnými př́pady, kdy herci na jevišti vystupovali ze svých rolí, neměla na význam událostí jakékoli dopady. Lze ale konstatovat, že k určitému dramaturgickému nesouladu došlo z pohledu očekávání relevantních aktérů a nás jako výzkumníků. Tento nesoulad se projevil ve výše zmíněném odlišném hodnocení významu akcí. To ve výsledku můžeme identifikovat jako jeden $z$ dalších limitů využití námi zvoleného př́stupu.

Náš text je možné uzavřít krátkou notickou týkající se možností dalšího výzkumu v této oblasti. Plzeňské Slavnosti svobody máme v plánu sledovat v delším časovém horizontu a pokusit se následně propojit data vytvořená prostřednictvím dramaturgické analýzy s daty, která budeme konstruovat pomocí strukturovaných a polostrukturovaných rozhovorů se zainteresovanými aktéry. Přitom se domníváme, že z dlouhodobé perspektivy je zajímavé to, zda se bude nějakým zpo̊sobem zásadně měnit (re)produkovaný diskurz ohledně těchto slavností. Dále jsme toho názoru, že dramaturgická analýza se i přes některé výše zmíněné limity osvědčila jako teoreticko-metodologický aparát, jehož optikou je možné nahlížet veřejné události, a to zejména díky možnostem jejich redukce do podoby divadelních představení, které se vždy řídí specifickým scénářem, a to navzdory skutečnosti, že některé analyzované události se snažily navodit dojem spontánnosti.

Zároveň je možné určitým způsobem zobecnit zjištění získaná v našem výzkumu, který tak přinesl poznatky týkající se nejenom konkrétní pozorované události. Souhlasíme s Goffmanem v tom, že pravidla chování na veřejných událostech mohou mít značnou vypovídající hodnotu o nastavení obecnějších pravidel fungování celé společnosti (Goffman 1966: 3-4). Podobný názor zastává i Jiř́ Šubrt (2001: 243): „Jakékoli organizované společenství lze podle Goffmana studovat dramaturgickým př́stupem, tedy z hlediska ovládání dojmů v dané instituci." Jedna z linií, ve kterých lze náś výzkum zobecnit, se tedy týká toho, že analýza veřejných událostí může sloužit jako nástroj k interpretaci celospolečensky platných norem a pravidel. Zároveň je možné zobecnit i kontext týkající se ideologického pozadí, se kterým souvisí schopnost navodit pocit 
sounáležitosti mezi členy společnosti a státním aparátem (Eagleton 2007: xxii). Z tohoto pohledu je tak možné provázat náš prŕstup s kritickým studiem konceptu ideologie. Tento pohled hovoří o tom, že „politická pravda je série událostí organizovaných do podoby masivní populární události““ (Badiou 2012: 85). A Slavnosti svobody představují právě jednu z těchto událostí, které je možné takto nahlížet jako nástroj pro šírení požadované ideologie (a na ní navázaných parciálních diskurzů). Výstupy z dramaturgické interpretace Slavností svobody je také možné přenést na obecnou rovinu legitimity daného hodnotového řádu. Tento vztah mezi sérií parciálních veřejných událostí a strukturální legitimitou lze nahlížet jednak tak, jak byl naznačen výše $\mathrm{v}$ textu, a zároveň je možné tento vztah přenést na obecnou rovinu. S ohledem na charakter analyzovaných akcí, jež z velké části nabíraly podoby Hobsbawmovo konstruování národních tradic (Hobsbawm a Ranger 1992), lze konstatovat, že jejich forma a obsah mohly vést k posilování strukturální legitimity díky tomu, že národní identita je obecně hodnotou politického života s nejsilnější legitimitou (srov. Anderson 2008: 18). A jelikož pro legitimitu daného hodnotového systému je důležité její normativní nastavení (Beetham 1991: 6), je možné vrátit se obloukem k možnostem dramaturgické analýzy pro výzkum legitimity.

Pokud se pokusíme zasadit náš text do širší výzkumné tradice, můžeme odkázat na celou řadu výzkumů, které řeší různá témata optikou podobnou té naší. Využití dramaturgické analýzy nalézáme u celé řady témat s politologií př́liš nesouvisejících, ale na druhou stranu existuje široké spektrum textů řešících prostřednictvím Goffmanova aparátu témata výsostně politologická. Variabilita zkoumaných témat, která lze uchopit tímto aparátem, je značná. To můžeme ilustrovat prostřednictvím některých zpracovaných témat. $\mathrm{V}$ českém prostředí může jít o některé naše další výzkumy související s dramaturgickým uchopením oslav výročí Slovenského národního povstání (Krčál a Naxera 2011 a Naxera a Krčál 2016), prípadně o text zabývající se několika provázanými tématy komunální politikou, reprodukcí sociálně vědního vědění formou konferencí a neonacistickými demonstracemi (Lupták a Krčál 2016). Ostatně demonstrace bývají optikou dramaturgické analýzy uchopovány poměrně často (Rosental 2013, Krčál 2015). Tento př́stup bývá využit také např́klad při výzkumu politických debat (např́klad v rámci předvolební kampaně vamerických prezidentských volbách v roce 2004 - viz Brown 2005) nebo lze poukázat na časté užití této analýzy v rámci výzkumu problematiky sociálního začleňování (Sohrabi a Farquharson 2015 nebo Ryan 2011). Z tohoto namátkového výčtu zpracovaných témat je patrné, že je možné identifikovat jeden stěžejní prvek procházející napříč tématy - veřejně prezentované formy lidského jednání (od demonstrací př̀es prezidentské volby až k integraci menšin), z čehož plyne relevance studia lidského jednání ve vztahu k politické vědě a možnost jeho uchopení prostř̌ednictvím dramaturgické analýzy. Tím se ostatně vracíme k tomu, co již bylo řečeno - že totiž pravidla organizace a jednání ve veřejném prostoru 
mají vypovídající hodnotu ve vztahu k normativnímu nastavení společnosti jako celku.

\section{Literatura a prameny}

Anderson, Benedict (2008): Prédstavy společenství: Úvaby o piovodu a šírení nacionalismu. Praha: Karolinum.

Badiou, Alain (2012): The Rebirth of Histoy. Times of Riots and Uprisings. London: Verso.

Beetham, David (1991): The Legitimitation of Power. Houndmills: Palgrave.

Blumer, Herbert (1969): Symbolic Interactionism: Perspective and Method. Berkley: University of California Press.

Blumer, Herbert (1972): „Action vs. Interaction: Relations in Public - Microstudies of the Public Order by Erving Goffman." Society 9: 50-53.

Branaman, Ann a Charles Lemmert (eds.) (1997): The Goffman Reader. Oxford: Blackwell Publishers.

Brown, Robert E. (2005): „Acting Presidential. The Dramaturgy of Bush Versus Kerry.“ American Behavioral Scientist 49 (1): 78-91. DOI: 10.1177/0002764205279397

Burzová, Petra, Dvořáková, Ilona, Hejnal, Ondřej, Růžička, Michal a Laco Toušek (2013): „Pamět’ a prostor: Reprezentační strategie společenstva vzpomínání v postindustriálním městě." Sociálni studia/Social Studies 10 (4): 107-126.

Burzová, Petra (2014): Politika poloverejnosti. Narativni analýza spori o demolici Domu hrüsy u Radbuzy. Brno: Doplněk.

Česká televize (2015): „Tanky a šeřky: Slavnosti svobody v Plzni vyurcholily préblídkou." Převzato z http://www.ceskatelevize.cz/ct24/regiony/1525312-tanky-a-serikyslavnosti-svobody-v-plzni-vyvrcholily-prehlidkou [ověreno ke dni 10. 1. 2016].

Eagelton, Terry (2007): Ideology. An Introduction. London: Verso.

Fairclough, Norman (2004): Analysing Discourse. Textual Analysis for Social Research. London: Routledge.

Goffman, Erving (1966): Behavior in Public Places. New York: The Free Press.

Goffman, Erving (1986): Frame Analysis. An Essay on the Organization of Experience. Boston: Northeastern University Press.

Goffman, Erving (1999): Všichni hrajeme divadlo. Sebeprez̧entace v každodenním životě. Praha: Ypsilon.

Gouldner, Alvin W. (1970): The Coming Crisis of Western Sociology. New York: Basic Books.

Hobsbawm, Erik a Terence O. Ranger (eds.) (1992): The Invention of Tradition. Cambridge: Cambridge University Press.

Keller, Jan (2003): Nedomy̌̌lená společnost. Brno: Doplněk.

Krčál, Petr a Vladimír Naxera (2011): „Veřejné akce jako divadelní představení.“ Stredoevropské politické studie 13 (1): 1-23.

Krčál, Petr (2015): Problematika legitimity ve společnosti po neoliberální revoluci (nepublikovaná disertační práce). Plzeň: ZČU.

Lakoff, George a Mark Johnson (2002): Metafory, kterými žijeme. Brno: Host.

Linz, Juan (2000). Totalitarian and Authoritarian Regimes. Boulder: Lynne Rienner Publishers. 
Lupták, Lubomír a Petr Krčál (2016): „Možnosti využití dramaturgické analýzy v politologii.“ (manuskript).

Naxera, Vladimír a Petr Krčál (2016): „Obrazy ne-bezpečnosti v projevech slovenských politiků." Politics in Central Europe 12 (1S) (v tisku).

Program Slavností svobody. Převzato $\mathrm{z}$ http://www.slavnostisvobody.cz/slavnostisvobody/program/ [ověřeno ke dni 12. 12. 2015].

Rosental, Claude (2013): „Toward a Sociology of Public Demonstrations.“ Sociological Theory 31 (4): 343-365. DOI: 10.1177/0735275113513454

Ryan, Louise (2011): „Moslim Women Negotiating Collective Stigmatization.“ Sociology 45 (6): 1045-1060. DOI: 10.1177/0038038511416170

Slavnosti svobody. Převzato z http://www.slavnostisvobody.cz/slavnostisvobody/slavnosti-svobody-2012.aspx [ověřeno ke dni 12. 12. 2015].

Sohrabi, Hadi a Karen Farquharson (2015): „Social Integration of Australian Muslims: A Dramaturgical Perspective." Journal of Sociology 2015: 1-16. DOI: $10.1177 / 1440783314562415$

Šubrt, Jiři (2001): „Dramaturgický př́stup Ervinga Goffmana. K českému vydání Goffmanovy knihy Všichni hrajeme divadlo.“ Sociologický časopis 37 (2): 241-249.

$Z$ Normandie až do Plžně. Převzato z http://www.slavnostisvobody.cz/ [ověřeno ke dni 12. 12. 2015].

\section{“Thanks, America!": A Dramaturgical Analysis of the Liberation Festival in the "Most American" City in Europe}

\section{SUMMARY}

The aim of this text is to introduce to the reader an interpretation of the $70^{\text {th }}$ anniversary of the Freedom Celebrations - an annual event devoted to the ceremonial celebration of the liberation of the City of Pilsen by allied American and Belgian forces. The Freedom Celebrations are de facto an umbrella term for a number of individual events taking place in various areas in and around Pilsen on various days. These events are joined together thematically by the ceremonial celebration of Pilsen's liberation at the end of the Second World War. They host a large number of observers and are also an opportunity for local, regional, and national political representatives to produce (or reproduce) discourses that are, from their standpoints, significant. These discourses are primarily connected to the celebration of democratic values and with the creation of metaphors for Russia as a threat and the United States as the defender of freedom and security in the present (and past) world. From this, we can infer the first interpretational thread that we will follow in the text, as we attempt to uncover the discursive processes behind the production (or reproduction) of themes invoked by the participating (local and national) political elites.

The second thread can be inferred from the fact that the Freedom Celebrations are a public event with a substantial number of observers. With this in mind, it is logical that these celebrations are an important focus for law enforcement agencies which attempt to 
ensure and maintain security at this event. From this perspective, the paper attempts to characterize the specific ways in which these elements serve public gatherings such as Pilsen's Freedom Celebrations as an event that helps to construct the perception of the state apparatus as the guarantor of the security of its "orderly citizens". The final line that we follow in our analysis of the Freedom Celebrations can be introduced by stating that a coherently and logically reproduced past may serve to strengthen a society's trust in the current value system by helping to present the historical interconnectedness of the values to which a given political system adheres. From this point of view, Pilsen's Freedom Celebrations can be perceived as a public event, the symbolic meaning of which lies in the veneration of democracy via a certain reference point, i.e. in this case the Second World War.

The data that we interpret in the text have been constructed on the basis of semiparticipant observations of selected events during the Freedom Celebrations from $2^{\text {nd }}$ to $6^{\text {th }}$ May, 2015. The second source of data was interviews with the actors involved. As a suitable tool for the interpretation of data, we chose Erving Goffman's dramaturgy analysis, which allows us to reduce and view public events as specific theatrical performances in which various actors attempt to evoke and maintain their preferred definitions of the situation. If we return to the two primary targets of our focus, we can argue that with respect to the thread of discourse production, the main actors are the local and national political elites and other individuals who make presentations at individual events in the role of "speaker". With respect to the organizational thread, we view the representatives of the national and municipal police as the main actors.

In this text, we also attempt to highlight that, although the role of war veterans is semantically and discursively accentuated, in reality these individuals can be perceived more as props or elements of the performance than as subjects of the celebrations. From an organizational perspective, we also focus on the fact that the selection of political actors in individual events is subject to fixed methods and is based on the positions of the representatives in the hierarchy of the leadership of the city (or at other levels) or on their political status. Participation in, and public appearances at such events can then heighten or solidify this status. The Freedom Celebrations can be perceived as an event that has fostered 1) the reproduction of the legitimacy of state apparatuses; 2) the construction or spread of the required discourse; and 3) the heightening or strengthening of the symbolic statuses of the actors involved.

If we return to the previously mentioned metaphors ("Russia as a security threat to Europe" and "the USA as a symbol of past and present freedom"), it is evident that, according to the interpretative part of the text, these metaphors have proven to be valid in the sense of being reproduced by all or a majority of the present political representatives (the "political team"). These metaphors have often merged, and Russia has been presented as a potential security problem that can and should be dealt with only with the co-participation of the USA, i.e. in a strong Euro-Atlantic alliance. Just as American and Soviet soldiers were portrayed differently in central Europe at the end of the war - Americans as liberators, Russians as tools of Stalin's imperialist ambitions - a similar dichotomy is used to interpret present American and Russian foreign policy: Russian interventions are still framed as manifestations of imperialism, while American interventions are framed as manifestations of the spread of peace and freedom. 